Biol. Stud. 2009: 3(2); 115-122 • DOI: https://doi.org/10.30970/sbi.0302.043

www.http://publications.Inu.edu.ua/journals/index.php/biology

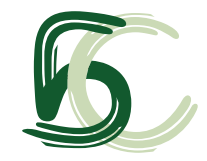

UDC 581.144.2+581.524+581.55

\title{
EVALUATION OF CRUDE OIL CONTAMINATED SOIL ON THE CONTENT OF PROLINE AND SOLUBLE SUGARS IN SEDGE (CAREX HIRTA L.) PLANT
}

\author{
H. Korovetska, O. Tsvilynjuk, O. Terek \\ Ivan Franko National University of Lviv, 4, Hrushevskyi St., Lviv 79005, Ukraine \\ e-mail: korovetska@gmail.com
}

Hydrocarbons of crude oil are highly toxic to plants, microorganisms, invertebrates and they constitute a potential risk to human health. Phytoremediation is an effective technology which uses plants for cleaning up petroleum contaminated soils. We determined concentrations of organic osmolites (proline and soluble sugars) for evaluation of application of Carex hirta L. plant for phytoremediation. Soil received $0 \%$ (control) and $5 \% \mathrm{v} / \mathrm{w}$ of oil. Concentration of proline in young and old leaves of sedge plant under oil pollution decreased (2-fold and 1.7-fold, respectively), whereas in rhizomes increased (1.3-fold), compared to the control. Content of soluble sugars increased in young leaves (3.3-fold) and significantly decreased in old leaves (3.6-fold) of C. hirta plant subjected to oil pollution. The level of soluble sugars in rhizomes of treated sedge plant increased (2.2-fold). Based on the obtained results, following conclusions were done: (a) proline (as osmoregulatory solute) is important for absorption and transportation of water through underground rhizomes of sedge plant; (b) soluble sugars have a great value for osmoregulation process in rhizomes and young leaves of these plants. Thus, C. hirta can sustain growth in oil polluted soils due to the increase of osmotic potential of cells. That is why, this plant may be a good candidate for phytoremediation.

Key words: Carex hirta, oil contamination, proline, soluble sugars.

\section{INTRODUCTION}

Fuel oil is a significant anthropogenic pollutant of the environment. It is estimated that $80 \%$ of terrestrial oil pollution is a result of spillage [8,21,22]. Crude oil spillage is a big problem in Boryslav oil region (Ukraine) as well. Petroleum is produced there mainly in the areas with agricultural activities. Therefore, the remediation of soil impacted by oil production and its transportation is important not only from the ecological point of view, but it is also important for preservation of agricultural productivity. Phytoremediation, a cost-effective in situ technology, uses plants and their rizosphere microorganisms in order to clean up petroleum contaminated soils [16]. 
When mixed with soil, oil acts as a physical barrier restricting oxygen movement into the soil, thus, reducing gas exchanges between plant roots and soil [18, 23]. Hydrophobic properties of petroleum reduce the wetability of oiled sediments and, in that way, water and nutrient availability for plants. The adaptive changes in plants which grow under oil pollution take place at all organization levels. Osmotic adjustment at the physiological level is an adaptive mechanism and it plays an important role in acclimatization of plants to stress conditions [4]. During the process of osmotic adjustment, a remarkable array of organic compounds (proline, glucose, sucrose, sorbitol, mannitol, etc.) and inorganic ions (mainly potassium) contribute to the solute potentials of plant cells and tissues [28].

Seeds of most plants which reproduct asexually can not germinate in polluted soil because of toxic influence of oil hydrocarbons. Carex hirta $L$. is one of the long-rhizomed species which can sustain growth and develop under toxic concentrations of oil in Boryslav region [6]. The results of research by Djura et al. (2006) [1] indicated that $C$. hirta plant also enhanced biodegradation of hydrocarbons in contaminated soils. The adaptation mechanisms of these plants, including osmoregulation, are not thoroughly examined. Therefore, the aim of our study was to determine the effect of crude oil towards concentrations of proline and soluble sugars in organs of $C$. hirta plant.

\section{MATERIALS AND METHODS}

\section{Preparation of artificial polluted soil}

The experiment was set-up in the Botanical garden of Ivan Franko L'viv National University. Half of containers were filled up with air-dried soil alone (control soil) and another half of containers were filled up with air-dried soil that was thoroughly mixed by hand with $5 \%(\mathrm{v} / \mathrm{w})$ of Boryslav crude oil (contaminated soil). Chemical properties of the crude oil are listed in the Table 1. Characteristics of both soils are presented in the Table 2. After 3 weeks C. hirta plants were put into the containers.

\section{Sample collection}

Destructive sampling was carried out in 60 days: shoots were cut at soil surface; roots were removed from the soil and washed up.

\section{Proline determination}

$0.3 \mathrm{~g}$ of fresh samples was homogenized in $5 \mathrm{ml}$ of distilled water. The homogenate was centrifuged at $3,000 \times \mathrm{g}$ for $10 \mathrm{~min}$. After addition of acid ninhydrin and glacial acetic acid, resulting mixture was heated at $100^{\circ} \mathrm{C}$ for $1 \mathrm{~h}$ in a water bath. The reaction was stopped by using ice bath. Absorbance of the mixture was measured at $520 \mathrm{~nm}$ using spectrophotometer („CФ 46” LOMO, Russian Federation). Proline concentration was expressed as $\mu$ mole proline per gram of fresh weight $[5,9]$.

\section{Soluble sugars measurement}

$0.5 \mathrm{~g}$ of fresh samples was homogenized in $5 \mathrm{ml}$ of ethanol and centrifuged at $5,000 \times \mathrm{g}$ for $15 \mathrm{~min}$. The supernatant was used for estimation of reducing sugars concentration by phenol-sulfuric acid method of Dubois et al. (1956) [15]. 
Table 1. Chemical properties of crude oil used in the experiments

Таблиця 1. Хімічні властивості нафти, використаної для досліду

\begin{tabular}{c|c}
\hline Sulfur & $1.90 \%$ \\
Heavy metals & \\
Cadmium & $2.7 \mathrm{ppm}^{* *}$ \\
Lead & $5.2 \mathrm{ppm}$ \\
Mercury & $4.2 \mathrm{ppm}$ \\
Nickel & $6.8 \mathrm{ppm}$ \\
\hline
\end{tabular}

* - Karpyn et al. (2009) [2].

${ }^{* *}$ ppm - parts per million.

Table 2. Characteristics of soils used in the experiments Таблиця 2. Характеристики ґрунтів, використаних у досліді

\begin{tabular}{l|c|c}
\hline & Control soil & Contaminated soil \\
\hline Texture & Loam & Loam \\
$\mathrm{pH}(\mathrm{KCl})$ & 5.26 & 4.83 \\
$\mathrm{Humus}, \%$ & 1.478 & 3.609 \\
$\left(\mathrm{NO}_{2}+\mathrm{NO}_{3}\right)-\mathrm{N}, \mathrm{mg} / \mathrm{kg}$ & 6.97 & 8.26 \\
$\mathrm{P}_{2} \mathrm{O}_{5}, \mathrm{mg} / \mathrm{kg}$ & 179 & 168 \\
$\mathrm{~K}_{2} \mathrm{O}, \mathrm{mg} / \mathrm{kg}$ & 105 & 118 \\
\hline
\end{tabular}

\section{Statistical analysis}

Each experiment was repeated three times and results were similar. Standard deviation was calculated, and statistical significance of difference was evaluated by using Student's t-test $(P<0.05)$.

\section{RESULTS AND DISCUSSION}

Cells of higher plants accumulate different amino acids (proline, serine, alanine, arginine, aspartic and glutamic acids) in response to environmental stresses [3]. Proline plays a crucial role as an osmoregulatory and osmoprotectant solute in plants subjected to hyperosmotic stresses. Proline accumulation has been proposed as a source of reduced nitrogen and carbon [28]. Also, proline synthesis may enhance activity of redox sensitive pathways such as the oxidative pentose phosphate pathway, which is dependent on NADP ${ }^{+}$availability and inhibited by NADPH [25].

The results of our investigation revealed that proline concentration in young and old leaves of treated sedge plants was respectively 2 -fold and 1.7 -fold lower than in the plants growing in the uncontaminated soil (see Fig. 1).

A large body of data indicates a positive correlation between proline accumulation and adaptation to stress $[12,17,20,24,26]$. However, this is not corroborated by other studies [7, 10, 13, 27]. The results of our work coordinate with point of view of second studies group, since correlation between proline content in leaves of $C$. hirta plant and adaptation to stress caused by crude oil was negative. On the other hand, crude oil contamination induced a 1.3-fold increase (comparing to the control) of proline level in 
rhizomes of sedge plants (see Fig. 1). It has been shown that single compounds such as proline minimize cellular damage by enhancing the stability of proteins and membranes [13]. As our study showed proline might possess protective properties even at low concentration. Thus, proline does not have direct role as an osmolyte in leaves, but it is necessary for absorption and transportation of water through underground rhizomes of $C$. hirta plant under oil pollution of soil.

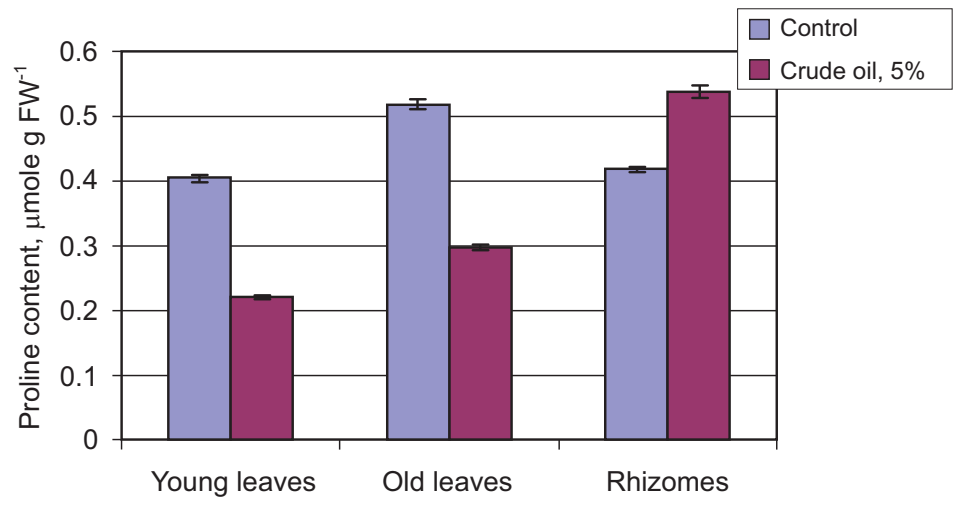

Fig. 1. The effect of crude oil polluted soil on the proline content in Carex hirta plant

Рис. 1. Вплив нафтового забруднення ґрунту на вміст проліну у рослинах Carex hirta

Sugars regulate the expression of many genes involved in photosynthesis, respiration, nitrogen and secondary metabolism, thus integrate cellular responses to stress [11]. Tolerance depends upon energy status of cells in which appropriate responses are induced. Many tissues of stressed plants are likely to have an increased requirement in rapidly metabolizable carbohydrate. This must be satisfied despite a likely decrease in carbon fixation and an increased diversion of carbon from growth or storage to osmolyte synthesis [17].

Our data showed that concentration of soluble sugars increased in young leaves (3.3-fold higher than in the control) and significantly decreased in old leaves (3.6-fold lower than in the control) of $C$. hirta plants subjected to oil pollution (see Fig. 2). A remarkable resistance to dehydration of the photosynthetic apparatus was observed, e.g. in lupins, especially in younger leaves [11]. Soluble sugars may act as osmoprotectant, as well as being a source of carbon that is necessary for maintenance and re-growth during recovery. In addition, water deficit resulting from oil pollution can inhibit starch synthesis and accelerate its decomposition. It is thought that decrease of starch and increase of soluble sugars can maintain cell turgor [28].

The level of soluble sugars was higher in rhizomes of sedge plants (2.2-fold higher than in the control) which has been growing in contaminated soil (see Fig. 2). The increase of soluble sugars concentration due to inversion of some carbohydrates is another adjustment mechanism that improves tolerance towards osmotic stress, as already reported [19].

The results obtained in our study indicate that proline (as osmoregulatory solute) is important for absorption and transportation of water through underground rhizomes 


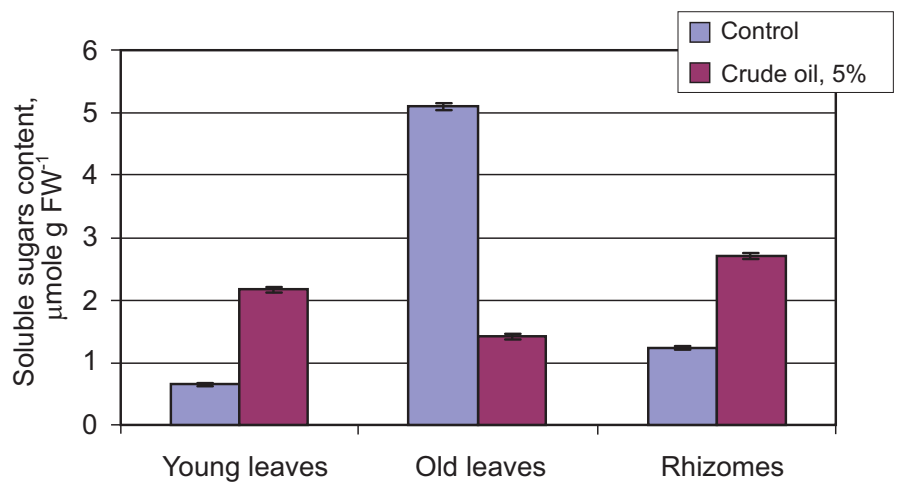

Fig. 2. The effect of crude oil polluted soil on soluble sugars content in Carex hirta plant

Рис. 2. Вплив нафтового забруднення ґрунту на вміст розчинних цукрів у рослинах Carex hirta

sedge plants, whereas soluble sugars are of great importance in osmoregulation process of rhizomes and young leaves. Obviously, C. hirta can sustain growth in oil polluted soils due to the increase of cells' osmotic potential. That is why this plant is a good candidate for phytoremediation.

\section{ACKNOWLEDGEMENTS}

We are grateful to Laslo Simon and Zoltan Dinya, College of Nyiregyhaza (Hungary), for their help in analysis of soil parameters and chemical properties of the crude oil used in the experiment.

This study was supported by grant of the West-Ukrainian BioMedical Research Center.

1. Джура Н.М., Романюк О.І., Гонсьор Я. та ін. Використання рослин для рекультивації ґрунтів, забруднених нафртою і нафтопродуктами. Екологія і ноосферологія, 2006; 17 (1-2): 42-52.

2. Карпин О., Джура Н., Цвілинюк О. та ін. Важкі метали як компонент нафртового забруднення грунту. Вісн. Львів. ун-ту. Сер. біол, 2009; 50: 177-181.

3. Клеточные механизмы адаптации растений к неблагоприятным воздействиям экологических факторов в естественных условиях / Под ред. чл.-кор. НАН Украины Е.Л. Кордюм. К.: Наук. думка, 2003. 277 с.

4. Терек О.І. Механізми адаптації та стійкості рослин до насприятливих фракторів довкілля. Журнал агробіології та екології, 2004; 1 (1-2): 41-56.

5. Холодова В.П., Волков К.С., Кузнецов Вл. В. Адаптиция к высоким концентрациям солей меди и цинка растений хрустальной травки и возможность их использования в целях фриторемедиации. Физиология растений, 2005; 52 (6): 848-858.

6. ЦЦайтлер М.Й. Заростання ділянок, забруднених нафтопродуктами (на прикладі Бориславського нафтового родовища). Науковий вісник. Львів: УкрДЛтУ, 1999; 99: 151-154.

7. Alian A., Altman A., Heuer B. Genotypic difference in salinity and water stress tolerance of fresh market tomato cultivars. Plant Science, 2000; 152: 59-65.

8. Amadi A., Dickson A.A., Maate G.O. Remediation of oil polluted soils: 1. Effect of organic and inorganic nutrient supplementes on the performance of maize (Zea may L.). Water, Air, and Soil Pollution, 1993; 66: 59-76. 
9. Bates L.S., Waldren R.P., Teare I.D. Rapid Determination of Free Proline for Water-Stress Studies. Plant Soil, 1973; 39: 205-207.

10. Chandler S.F., Thorpe T.A. Proline accumulation and sodium sulfate tolerance in callus cultures of Brassica napus L. Cv. Westar. Plant Cell Rep, 1987; 6: 176-179.

11. Chaves M.M., Pereira J.S., Maroco J. et al. How Plants Cope with Water Stress in the Field. Photosynthesis and Growth. Annals of Botany, 2002; 89: 907-916.

12. Chou I.T., Chen C.T., Kao C.H. Characteristics of the introduction of the accumulation of the proline by abscisic acid isobutyric acid in detached rice leaves. Plant Cell Physiol, 1991; 32: 269-272.

13. Csonka L.N. Physiological and genetic responses of bacteria to osmotic stress. Microbiological Review, 1989; 53: 121-293.

14. Delauney A.J., Verma D.P.S. Proline biosynthesis and osmoregulation in plants. The Plant Journal,1993; 4 (2): 215-223.

15. Dubois M., Gilles K.A., Hamilton J.K. et al. Calorimetric method for determination of sugars and related substances. Anal. Chem, 1956; 28: 350-356.

16. Frick C.M., Farrell R.E., Germida J.J. Assessment of Phytoremediation as an In-Situ Technique for Cleaning Oil-Contaminated Sites. Department of Soil Science University of Saskatchewan Saskatoon, SK Canada S7N 5A8, 1999; 23-25.

17. Hare P.D., Cress W.A., Van Staden J. Dissecting the roles of osmolyte accumulation during stress. Plant, Cell and Environment, 1998; 21: 535-553.

18. Meudec A., Poupart N., Dussauze J., Deslandes E. Relation between heavy fuel oil phytotoxicity and polycyclic aromatic hydrocarbon contamination in Salicornia fragilis. Science of the Total Environment, 2007; 381: 146-156.

19. Mohsenzadeh S., Malboobi M.A., Razavi K., Farrahi-Aschtiani S. Physiological and molecular responses of Aeluropus lagopoides (Poaceae) to water deficit. Environmental and Experimental Botany, 2006; 56: 314-322.

20. Munns R., Brady C.J., Barlow E.W. Solute accumulation in the apex and leaves of wheat during water stress. Aust. J. Plant Physiol, 1979; 6: 379-389.

21. Odu C. T. I. Microbiology of soils contaminated with petroleum hydrocarbons Natural rehabilitation and reclamation of soil affected. Inst. Petroleum Technol. Publ, 1977; 1: 77-105.

22. Ogboghodo I. A., Iruaga E. K., Osemwota S. I. O., Chokor J. U. An assessment of the effects of crude oil pollution on soil properties, germination and growth of maize (Zea mays) using two crude types - forcados light and escravos light. Environmental Monitoring and Assessment, 2004; 96: 143-152.

23. Osuji L. C., Egbuson E. J. Ojinnaka C. M. Assessment and treatment of hydrocarbon inundated soils using inorganic nutrient (N-P-K) supplements: II. A case study of eneka oil spillage in Niger Delta, Nigeria. Environmental Monitoring and Assessment, 2006; 115: 265-278.

24. Rhodes D., Handa S., Bressan R.A. Metabolic changes associated with adaptation of plant cells to water stress. Plant Physiol, 1986; 82: 890-903.

25. Sánchez F.J. E.F. de Andre's, Tenorio J.L., Ayerbe L. Growth of epicotyls, turgor maintenance and osmotic adjustment in pea plants (Pisum sativum L.) subjected to water stress. Field Crops Research, 2004; 86: 81-90.

26. Szoke A., Miao G.-H., Hong Z., Verma D.P.S. Subcellular location of $\Delta^{1}$-pyrroline-5-carboxylate reductase in root/nodule and leaf of soybean. Plant Physiol, 1992; 99: 1642-1649.

27. Trotel-Aziz P., Niogret M.-F., Larher F. Proline level is partly under the control of abscisic acid in canola leaf discs during recovery from hyper-osmotic stress. Plant Physiol, 2000; 110: 376-383.

28. Xu S., An L., Feng H., Wang X., Li X. The seasonal effects of water stress on Ammopiptanthus mongolicus in a desert environment. Journal of Arid Environments, 2002; 51: 437-447. 


\title{
ВПЛИВ НАФТОВОГО ЗАБРУДНЕННЯ ҐРУНТУ НА ВМІСТ ПРОЛІНУ ТА РОЗЧИННИХ ЦУКРІВ У РОСЛИНАХ OCOKИ (CAREX HIRTA L.)
}

\author{
Г. Коровецька, О. Цвілинюк, О. Терек \\ Львівський національний університет імені Івана Франка \\ вул. Грушевського, 4, Львів 79005, Україна
}

Вуглеводні нафтт є високотоксичними для рослин, мікроорганізмів, безхребетних тварин та небезпечними для здоровя людини. Фіторемедіація $є$ ефективною технологією, яка використовує рослини для очищення нафтозабруднених грунтів. Визначено вміст органічних осмолітів (вільного проліну та цукрів) у рослинах Carex hirta L. для оцінки використання цих рослин у фіторемедіації. Ґрунт містив 0\% (контроль) і 5\% сирої нафти. Вміст проліну у молодих і старих листках рослин C. hirta за дії нафти зменшився у 2 та 1,7 разу, відповідно, тоді як у кореневищах підвищився в 1,3 рази щодо контролю. За дії нафтового забруднення ґрунту рівень розчинних цукрів зріс у молодих листках (у 3,3 рази) і суттєво знизився у старих листках (3,6 рази) рослин C. hirta. Кількість розчинних цукрів у кореневищах рослин осоки шорстковолосистої, що зростала на забрудненому нафтою ґрунті зросла у 2,2 рази. Із отриманих результатів можна зробити такі висновки: (а) пролін (як осморегулятор) важливий для поглинання та транспортування води підземними кореневищами рослин осоки шорстковолосистої; (б) розчинні цукри мають суттєве значення в осморегуляційних процесах і у кореневищах, і у молодих листках цих рослин. Рослини C. hirta можуть зростати на забруднених нафтою ґрунтах за рахунок підвищення осмотичного потенціалу клітин. Тому ця рослина може бути добрим кандидатом для фріторемедіації.

Ключові слова: Carex hirta, нафтове забруднення, пролін, розчинні цукри.

\section{ВЛИЯНИЕ НЕФТЯНОГО ЗАГРЯЗНЕНИЯ ПОЧВЫ НА СОДЕРЖАНИЕ ПРОЛИНА И РАСТВОРИМЫХ САХАРОВ B РАСТЕНИЯХ ОСОКИ (СAREX HIRTA L.)}

\author{
Г. Коровецкая, О. Цвилынюк, О. Терек \\ Львовський национальный университет имени Ивана Франко \\ ул. Грушевского, 4, Львов 79005, Украина
}

Углеводороды нефти высокотоксичны для растений, микроорганизмов и беспозвоночных и опасны для здоровя человека. Фиторемедиация является эффективной технологией, которая использует растения для очистки загрязненных нефтью почв. Исследовано содержание органических осмолитов (свободного пролина и сахаров) в растениях Carex hirta L. для оценки использования этих растений в фриторемедиации. В состав почвы входило 0\% (контроль) и 5\% сырой нефрти. Содержание пролина в молодых и старых листьях растений C. hirta уменьшалось в 2 и 1,7 раза соответственно, тогда как в корневищах повысилось в 1,3 раза. Под влиянием нефтяного загрязнения почвы уровень растворимых сахаров повысился 
в молодых листьях (в 3,3 раза) и существенно снизился в старых листьях (в 3,6 раза) растений C. hirta. Количество растворимых сахаров в корневищах растений осоки жестковолосистой, которая росла на загрязненной нефтью почве, увеличилось в 2,2 раза. На основании полученных даных можно сделать следующие выводы: (а) пролин (как осморегулятор) важен для поглощения и транспортировки воды подземными корневищами растений осоки жестковолосистой; (б) растворимые сахара имеют большое значение в осморегуляционных процессах как в корневищах, так и в молодых листьях этих растений. Очевидно, рост C. hirta на загрязненных нефтью почвах возможен за счет повышения осмотического потенциала клеток. Поэтому это растение можно использовать для фиторемедиации.

Ключевые слова: Carex hirta, нефтяное загрязнение, пролин, растворимые caxapa. 